\title{
An Exploratory Study on the Factors Contributing Loan Repayment Default among the Loan Borrowers in Micro Finance Institutions in Shah Alam, Selangor
}

\author{
Uma Murthy $^{1} \&$ Paul Anthony Mariadas ${ }^{2}$ \\ ${ }^{1}$ Global Leadership Research Unit, Malaysia \\ ${ }^{2}$ Faculty of Business, Accountancy and Management, SEGi University, Malaysia \\ Correspondence: Uma Murthy, Global Leadership Research Unit, Malaysia. E-mail: umamurthy@segi.edu.my
}

Received: February 15, 2017

Accepted: October 11, 2017

Online Published: November 20, 2017

doi:10.5539/ijbm.v12n12p242

URL: https://doi.org/10.5539/ijbm.v12n12p242

\begin{abstract}
This research is carried out to discover the factors contributing to loan repayment default in micro finance institutions based in Shah Alam, Selangor, Malaysia. The findings will be useful for the micro finance institutions in Malaysia in selecting and implementing suitable policies to reduce defaults. In this research, data is collected through questionnaires. These questionnaires are distributed to 120 loan borrowers of micro finance institution in Shah Alam, Selangor. Furthermore, the data was analyzed with the software known as Statistical package for Social Science, for short SPSS. This study established that nature of business operated by loan borrowers is one of the factors that will influence loan repayment. Finding of this study are established that there is a positive relationship between nature of business operation and negative relationship between age of borrowers, diversion of funds by borrowers as well as repayment schedule to loan defaults.
\end{abstract}

Keywords: loan default, loan repayment and loan borrowers

\section{Introduction}

Micro finance is a mechanism that is used to alleviate poverty as well as to promote entrepreneurial development. It can be referred to the financial instruments that are tailored to the poor, such as loans, insurance and savings. However, in Malaysia, micro finance institutions (MFIs) provide only micro credit loans instead of providing other micro finance services together such as insurance and savings. Micro finance usually targets to micro enterprise or low-income households as these people normally lack of collateral, do not have steady employment and a verifiable credit history, which hinders them from gaining access to normal banking. Loans are more accessible to these people with the introduction of micro finance because of waived requirements for collateral or guarantors (Norhaziah \& Mohd Noor, 2013).

There are few micro finance institutions in Malaysia such as Yayasan Usaha Maju (YUM) and The Economic Fund for National Entrepreneurs Group (TEKUN). YUM provides loans to the poor people in Sabah while TEKUN offers loan to people throughout Malaysia. Both of these micro finance institutions offer loans based on individual lending scheme and they have a standardized lending contract. For example, YUM imposes weekly loan payments on all business types (YUM, 2009); TEKUN offers reasonable grace periods to borrowers depending on the harvesting cycles of their business (TEKUN, 2009).

\section{Literature Review}

\subsection{The Definition of Loan Repayment Default}

Micro finance is an effective tool to reduce poverty [Sayed, Izaidin, Syaiful, Muhamad, Sarah \& Nlizwa (2015); and Norma \& Jarita (2011)]. The concept of micro finance has been introduced in the 1700s in Ireland (Sayed et al., 2015). As time goes by, there are widespread successes of several microfinance programs around the world, such as Bangladesh's Grameen Bank, Bank Rakyat Indonesia, ACCION in Latin America, the Center for Agriculture and Rural Development (CARD) in Philippines and so on. Due to these successes, micro finance has been used as one of the instruments to achieve the United Nations' Millennium Development Goals of halving the rate of poverty by 2015 (Norma \& Jarita, 2011). 
Despite the success of micro finance around the world, the growth of micro finance is affected by loan repayment problems which are also known as loan repayment defaults. Bloem \& Gorter (2001) have defined loans default as the loans left unpaid for a period of 90 days. Also, the definition of default defined by Consultative Group to Assist the Poor (CGAP) 2009 is "when a borrower could not or will not pay back his or her loan and when the MFI no longer expects to be repaid (even though it keeps attempting to collect)".

\subsection{Nature of Business Operation}

There are several natures of business a micro credit loan borrower can operate in. Borrowers can utilize the loans in agricultural sector such as paddy husking, crop trading and cattle fattening. They can also utilize the loan for small business activity. In this research, the nature of business operated is defined as the business sector that the loan borrowers choose to operate in. (Mokhtar, Gilbert \& Christopher, 2012)

In the research conducted by Roslan \& Abd Karim (2009) to investigate loan repayment behavior by borrowers from AgroBank Malaysia, it has been found out that the nature of business operated by borrowers have an impact on the loan repayment default. Roslan and Abd Karin (2009) have confirmed that the loan borrowers who operate in non-production oriented business such as in the service sector have lower rate of defaulting. Chaudhary \& Ishafq (2003) have also found out that the loan borrowers who involved in non-farm business activity will have higher rate of repayment as compared to those who involved in farming activity. In other words, these borrowers will have lower probability of defaulting their loans.

\subsection{Age of Borrowers}

In Malaysia, people who are 18 years old to 60 years old are eligible to apply for the micro credit loans offered by the micro finance institutions such as TEKUN and YUM (TEKUN, 2013 and YUM, 2014). In this research, age of borrowers is defined as the age of the borrowers at the time they apply for micro credit loan. (Fikirte, 2011).

In a research conducted by Arene (1993), the age of borrowers are found out to be one of the factors that affect loan repayment default. Other researchers such as Kashuliza (1993), Eze and Ibekwe (2007) and Wongnaa \& Awunyo (2013) have also determined that age of borrowers will affect the loan repayment performance.

Fikirte (2011) has conducted a study on the determinants of loan repayment performance in Addis Credit and Saving Institution in Ethiopia. The researcher found out that age of borrowers has a relationship with loan repayment defaults. The higher the age of borrowers, the lower the rate of loan repayment defaults. According to Shaik (2014), the loan borrowers at younger stages have higher default rates than those who are at older age. The youngsters do not have much experience in managing their wealth and therefore they have higher rate of loan default.

\subsection{Diversion of Funds by Borrowers}

Diversion of funds is defined as the funds given to the borrowers are not utilized for the agreed and intended purpose. Loans are often diverted by the borrowers because of better opportunities or emergencies. In this research, diversion of funds is defined as the loans given to the borrowers are utilized for another purposes rather than the intended purpose. (Rashid, 2014)

Researchers such as Walter \& Lilian (2013), Ahmad (1997) and Wongnaa \& Awunyo (2013) have found out that diversion of funds by borrowers has been one of the factors of loan default. The study that carried out by Njoku (1997) to examine the determinants of loan repayment under the Special Emergency Loan Scheme (SEALS) in Nigeria has also found out that the diversion of loan to non-agricultural business will contribute to loan repayment defaults. This study has found out some of the loan borrowers will divert their micro credit loans to other usage such as paying medical expenses and school fees.

\subsection{Repayment Schedule}

Charles, Raphael, Dorcas and Kwadwo (2013) has defined repayment schedule as the time that loan borrowers are supposed to pay for it. Repayment schedule guides the loan borrowers in their repayment process.

Each micro finance institution has different repayment schedule. According to Charles et al. (2013), the repayment schedule for micro finance loans in Ghana is 14 months. However in Malaysia, the repayment schedule is 6 months to 10 years for TEKUN (TEKUN, 2013); while for YUM, the repayment schedule is on weekly basis after the loan is disbursed (YUM, 2014).

There are several studies that show repayment schedule will affect the loan repayment defaults. Nawai \& Mohd Shariff (2013) has found out the fact that when the business of the loan borrowers do not have enough of return to cover the scheduled payment on the repayment day, the loan borrowers will choose to defaulting their loans. 
Therefore, there is a relationship between the repayment schedule and loan repayment defaults. The researchers have found out that loan borrowers who repay their loans on a monthly-basis are good borrowers than default borrowers.

\section{Proposed Framework}

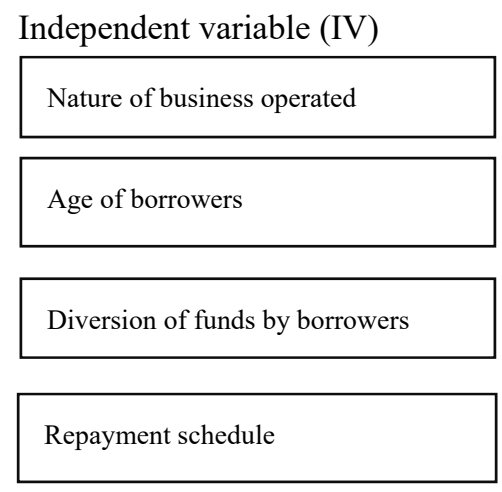

Dependent Variable (DV)

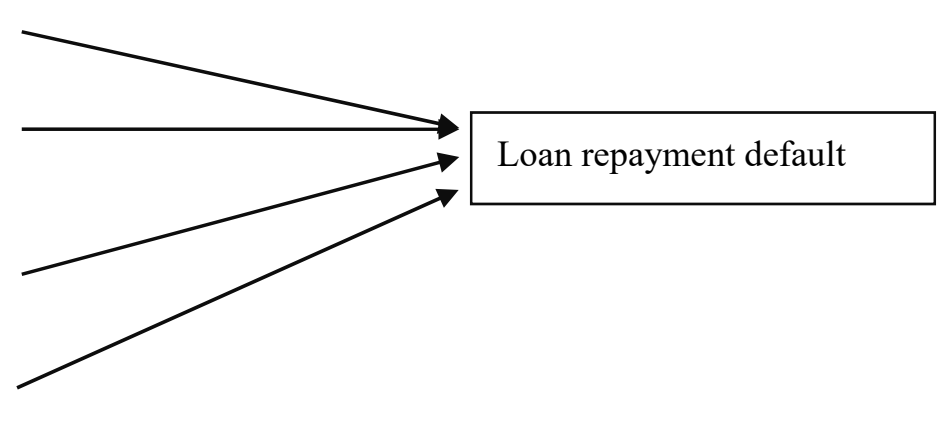

Figure 1. Research framework

Source: Munene \& Guyo (2013); Shaik (2014); Walter \& Lilian (2013); Nawai \& Mohd Shariff (2013).

\section{Research Hypotheses}

H1: There is a positive relationship between the nature of business operated and loan repayment default in micro finance institutions.

$\mathrm{H} 2$ : There is a positive relationship between the age of borrowers and loan repayment default in micro finance institutions.

H3: There is a positive relationship between the diversion of funds by borrowers and loan repayment default in micro finance institutions.

H4: There is a positive relationship between the repayment schedule and loan repayment default in micro finance institutions.

\section{Research Methodology}

\subsection{Measurement and Collection of Data}

A quantitative research approach is employed in this research following the positivist assumption with a realist ontology and objectivist epistemology. Data was collected using a face to face interviews, various questionnaires and conclude observations with questionnaires as the main method of collecting data. The adapted survey questionnaire employed in this study is divided into two sections; demography and scales of the four (5) underlying factors of the research instrument, capturing four (4) independent variables and 1 dependent variables. A 5-point Likert scale was used showing (1)"strongly disagree", (2) "disagree", (3) "slightly agree", (4) "agree", (5) "strongly agree". The cronbach alphas of all 20 items in the scale shows 0.758 , above and over 0.7 cut off threshold (Sekaran \& Bougie) which suggest that the reliability of the scales for measuring credit card spending, bank policies, financial planning, attitude towards money and fresh graduate bankruptcy are considered acceptable (Sekaran \& Bougie, 2010).

\subsection{Reliability Test}

Table 1. Reliability analysis

\begin{tabular}{lll}
\hline Variable & Cronbach's Alpha & Number of Items \\
\hline Loan Repayment Default & 0.748 & 6 \\
Nature of business operated & 0.898 & 4 \\
Age of borrowers & 0.906 & 5 \\
Diversion of funds by borrowers & 0.831 & 6 \\
Repayment Schedule & 0.810 & 3 \\
Average (All scales) & 0.828 & 24 \\
\hline
\end{tabular}


According to Table 1, the dependent variable (loan repayment default) and independent variables (nature of business operated, age of borrowers, diversion of funds by borrowers and repayment schedule) have Cronbach's Alpha value exceeded the prescribed threshold of 0.7. According to Nunnally (1981), the accepted Cronbach's Alpha value is 0.7 to prove that the scale items are sufficiently reliable to be tested. As the Cronbach's Alpha value for all scale items is 0.828 , this indicates that the variables used in the questionnaire are reliable.

\section{Data Analysis}

\subsection{Correlation Analysis}

Table 2. Correlation Analysis

\begin{tabular}{|c|c|c|c|c|c|c|}
\hline \multicolumn{7}{|c|}{ orrelations } \\
\hline & & DV_LRD & IV1_NBO & IV2_AB & IV3_DF & IV4_RS \\
\hline \multirow[t]{3}{*}{ DV_LRD } & Pearson Correlation & 1 & $.439^{\prime \prime}$ & .051 & $.267^{\prime \prime}$ & .218 \\
\hline & Sig. (2-tailed) & & .000 & .577 & .003 & .017 \\
\hline & $\mathrm{N}$ & 120 & 120 & 120 & 120 & 120 \\
\hline \multirow[t]{3}{*}{ IV1_NBO } & Pearson Correlation & $.439^{\prime \prime}$ & 1 & .067 & $.342^{m}$ & $.342^{\prime \prime}$ \\
\hline & Sig. (2-tailed) & .000 & & .468 & .000 & .000 \\
\hline & $\mathrm{N}$ & 120 & 120 & 120 & 120 & 120 \\
\hline \multirow[t]{3}{*}{ IV2_AB } & Pearson Correlation & .051 & -.067 & 1 & -.016 & -.124 \\
\hline & Sig. (2-tailed) & .577 & .468 & & .863 & .179 \\
\hline & $\mathrm{N}$ & 120 & 120 & 120 & 120 & 120 \\
\hline \multirow[t]{3}{*}{ N3_DF } & Pearson Correlation & $.267^{\prime \prime}$ & $.342^{\prime \prime}$ & -.016 & 1 & $.303^{\prime \prime}$ \\
\hline & Sig. (2-tailed) & .003 & .000 & .863 & & .001 \\
\hline & $\mathrm{N}$ & 120 & 120 & 120 & 120 & 120 \\
\hline \multirow[t]{3}{*}{ N4_RS } & Pearson Correlation & $.218^{\circ}$ & $342^{\prime \prime}$ & -.124 & $.303^{\prime \prime}$ & 1 \\
\hline & Sig. (2-tailed) & .017 & .000 & .179 & .001 & \\
\hline & $\mathrm{N}$ & 120 & 120 & 120 & 120 & 120 \\
\hline
\end{tabular}

Table 2 shows the relationship between dependent variable (loan repayment default) and all the independent variables (nature of business operated, age of borrowers, diversion of funds by borrowers and repayment schedule). The correlation coefficient between loan repayment default and nature of business operated is 0.439 . This represents moderate correlation between these two variables. Next, the correlation coefficient between loan repayment default and the age of borrowers is 0.051 , which is very low correlated. It means that these variables are not relative connected to each other. Thirdly, the correlation coefficient between loan repayment default and diversion of funds by borrowers is 0.267 , which indicates low correlated. It can be said that both of these variables are not that relative to each other. Lastly, the result shows a low correlation between loan repayment default and repayment schedule as the correlation coefficient between these variables is 0.218 .

\subsection{Multiple Regression Analysis}

Table 3. Model Summary

Model Summary
\begin{tabular}{|l|c|r|c|c|c|}
\hline Model & R & R Square & $\begin{array}{c}\text { Adjusted R } \\
\text { Square }\end{array}$ & $\begin{array}{c}\text { Std. Error of } \\
\text { the Estimate }\end{array}$ & $\begin{array}{c}\text { Durbin- } \\
\text { Watson }\end{array}$ \\
\hline 1 & $.467^{\text {a }}$ & .218 & .190 & .59782 & 1.848 \\
\hline
\end{tabular}
a. Predictors: (Constant), IV4_RS, IV2_AB, IV3_DF, IV1_NBO
b. Dependent Variable: DV_LRD

\subsection{Model Summary}

Based on Table 3, the Durbin Watson of this model is 1.848 . This represents there is no autocorrelation in this sample. Besides that, the R Square of this model is $0.218(21.8 \%)$. This can be interpreted as $21.8 \%$ of the independent variables such as nature of business operated, age of borrowers, and diversion of funds by borrowers and repayment schedule have a significance impact on loan repayment default as they are directly affecting loan repayment default. In other words, $21.8 \%$ of the changes in loan repayment can be attributed to the combined effect of the independent variables (nature of business operated, age of borrowers, diversion of funds by borrowers and repayment schedule). The remaining $78.2 \%$ of the variance in loan repayment default may be influenced by other variables which are not covered in this research. 
Table 4. ANOVAa

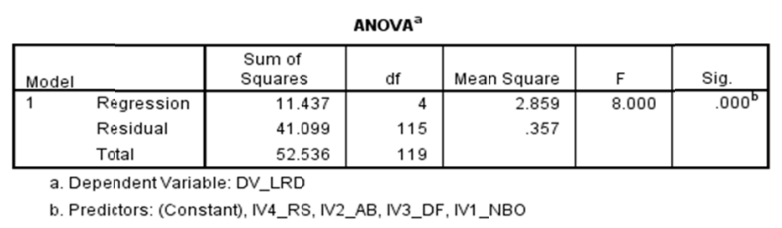

Table 4 shows the output of the Anova analysis and indicates whether there is statistically significant difference between the variables. The significant value ( $\mathrm{P}$ value) should be smaller than 0.05 . Based on Table 4.17 , the significant value is 0.000 , which is below 0.05 . This indicates there is a statistically significant difference between the dependent variable (loan repayment default) and independent variables (nature of business operated, age of borrowers, diversion of funds by borrowers and repayment schedule). Getting a P-value of 0.000 also means that this model is fit to use.

Table 5. Coefficients ${ }^{\mathrm{a}}$

\begin{tabular}{|c|c|c|c|c|c|c|c|c|}
\hline \multicolumn{9}{|c|}{ Coefficients $^{\mathbf{a}}$} \\
\hline \multirow[b]{2}{*}{ Model } & & \multicolumn{2}{|c|}{ Unstandardized Coefficients } & \multirow{2}{*}{$\begin{array}{c}\text { Standardized } \\
\text { Coefficients } \\
\text { Beta }\end{array}$} & & \multirow[b]{2}{*}{ sig. } & \multicolumn{2}{|c|}{ Collinearity Statistics } \\
\hline & & B & Std. Error & & & & Tolerance & VIF \\
\hline 1 & (Constant) & 1.839 & .485 & & 3.793 & .000 & & \\
\hline & IV1_NBO & .310 & .074 & .383 & 4.202 & .000 & .819 & 1.220 \\
\hline & IV2_AB & .065 & .062 & .087 & 1.040 & .300 & .983 & 1.017 \\
\hline & IV3_DF & .119 & .090 & .119 & 1.323 & .188 & .843 & 1.186 \\
\hline & IV4_RS & .047 & .069 & .062 & .685 & 495 & .833 & 1.200 \\
\hline
\end{tabular}

A regression equation can be generated from the results obtained in Table 5:

Loan Repayment Default $=1.839+0.310$ (Nature of business operated $)+0.065$ (Age of borrowers $)+0.119$ (Diversion of funds by borrowers) +0.047 (Repayment schedule)

According to the regression equation above, a unit increase in nature of business operated will increase loan repayment default by 0.310 . When there is a unit increase in age of borrowers, loan repayment default will increase by 0.065 . It can also be seen that a unit increase in diversion of funds by borrowers will increase loan repayment default by 0.119 . Lastly, a unit increase in repayment schedule will lead to an increase in loan repayment default by 0.047 .

The Table 5, independent variables such as age of borrowers, diversion of funds by borrowers as well as repayment schedule are not statistically significant as their p-values are greater than 0.05 . The P-values for these variables are $0.300,0.188$ and 0.495 respectively. However, the independent variable of nature of business operated is significant because its p-value is 0.000 .

To measure whether there is multicollinearity, variance inflation factor (VIF) is used. Based on Table 4.18, the VIF for each independent variable exceeds 1. The results show VIF for nature of business operated, age of borrowers, diversion of funds by borrowers and repayment schedule are 1.220, 1.017, 1.186 and 1.200 respectively. These represent that the independent variables may be moderately correlated, but not to be overly concerned about.

\subsection{Hypotheses Result}

Table 6. Hypothesis Result

\begin{tabular}{|c|c|c|c|c|}
\hline & Hypothesis & $\begin{array}{l}\text { Significant } \\
\text { Level }\end{array}$ & Result & $\begin{array}{l}\text { Gradient } \\
(\text { Beta, } \beta) \\
\end{array}$ \\
\hline $\mathrm{H}_{1}$ & $\begin{array}{l}\text { There is a positive relationship between the nature of business operated and loan } \\
\text { repayment default in micro finance institutions. }\end{array}$ & 0.000 & Supported & 0.310 \\
\hline $\mathrm{H}_{2}$ & $\begin{array}{l}\text { There is a positive relationship between the age of borrowers and loan repayment } \\
\text { default in micro finance institutions. }\end{array}$ & 0.300 & $\begin{array}{l}\text { Not } \\
\text { Supported }\end{array}$ & 0.065 \\
\hline $\mathrm{H}_{3}$ & $\begin{array}{l}\text { There is a positive relationship between the diversion of funds by borrowers and } \\
\text { loan repayment default in micro finance institutions. }\end{array}$ & 0.188 & $\begin{array}{l}\text { Not } \\
\text { Supported }\end{array}$ & 0.119 \\
\hline $\mathrm{H}_{4}$ & $\begin{array}{l}\text { There is a positive relationship between the repayment schedule and loan } \\
\text { repayment default in micro finance institutions. }\end{array}$ & 0.495 & $\begin{array}{l}\text { Not } \\
\text { Supported }\end{array}$ & 0.047 \\
\hline
\end{tabular}




\subsection{Discussion of Findings}

The first research objective of this research is to find the relationship between the nature of business operated and loan repayment default in micro finance institution in Malaysia. According to the analysis mentioned in previous chapter, the $p$-value of nature of business operated is 0.000 , which means there is a positive relationship between nature of business operated and loan repayment default. Thus, the hypothesis (H1) is accepted. This result is consistent with the study conducted by Roslan and Abd Karim (2009); Chaudhary and Ishafq (2003), who has established a positive relationship between nature of business operated and loan repayment default as well. The empirical study conducted by Mokhtar, Gilbert \& Christopher (2012) has also stated that nature of business operated by borrowers can affect loan repayment default in micro finance institutions.

The next research objective is to identify the relationship between the age of borrowers and loan repayment default in micro finance institutions. Based on the results obtained from SPSS analysis, the p-value of age of borrowers is 0.300 . As the p-value exceeds 0.05 , this variable is insignificant, which means there is negative relationship between age of borrowers and loan repayment default. In other words, the hypothesis (H2) is not accepted. The result obtained in this research is contradicted with the results obtained by Fikirte (2011), who states that the higher the age of borrowers, the lower the rate of loan repayment defaults. Empirical studies conducted by Shaik (2014) and Arene (1993) have also established positive relationship between age of borrowers and loan repayment default.

The third research objective is to identify the relationship the diversion of funds by borrowers and loan repayment default. According to the result obtained from SPSS analysis, the p-value obtained for this variable is 0.188 . With its $p$-value exceeding 0.05 , this variable is insignificant. This result shows that there is negative relationship between diversion of funds and loan repayment default. Therefore, the hypothesis (H3) is rejected. This result is consistent with the findings obtained by Kibrom (2010), which states that diversion of funds by the borrowers has no impact on loan repayment default. However, several empirical studies such as Walter and Lilian (2013); Ahmad (1997); Wongnaa amd Awunyo (2013) have found out that diversion of funds by borrowers has been one of the factors of loan default.

The last research objective of this study is to determine the relationship between repayment schedule and loan repayment default. Based on the result obtained from SPSS analysis, the p-value of this variable is 0.495 , which is more than 0.05 . This means that there is negative relationship between repayment schedule and loan repayment default. Therefore, the hypothesis (H4) is rejected. This result is consistent with what Dadson (2012) has found. However, it is contradicting to the result obtained by Field \& Pande (2008) and Guttman (2007).

\section{Implication of the Study}

This study is to determine the factors affecting loan repayment default within micro finance institution. This research would be beneficial to few parties such as the microfinance institutions, other lending institutions, banking industry as well as the future researchers.

Arising from this research, the microfinance institutions in Malaysia are able to identify how repayment schedule can affect repayment performance of the loan borrowers. By gaining this knowledge, they may re-strategize their repayment schedule in order to solve the increasing rate of loan repayment default.

Besides microfinance institutions, other lending institutions and banks can also gain information about the determinants of loan repayment default among the loan borrowers from this research. As most of the borrowers have identical characteristics, these institutions can be aware of the factors affecting the repayment performance of loan borrowers.

Apart from that, this research provides a useful reference document for the financial institutions to determine the factors affecting loan repayment default among the loan borrowers. The findings of this research are crucial for the institutions so that they are able to implement relevant policies to ensure they maintain a performing portfolio and improve their future profit margins.

Also, this research finding will provide future researchers who would like to find out more on the factors affecting loan repayment defaults in Malaysia.

\section{Recommendation for the Future Research}

Arising from this research, there are several areas are recommended for future research. First, this research is only focusing on the factors influencing loan repayment default within the microfinance institution in Shah Alam, Selangor. It is therefore recommended a similar study to be conducted covering other areas to compare the findings. 
Next, future researchers are recommended to conduct similar study focusing on other independent variables such as institutional characteristics and macroeconomic variables on loan repayment default within microfinance institutions in Malaysia.

In addition, similar survey to this research can be conducted after few years to determine if the factors influencing loan repayment default have changed as more microfinance institutions are established in Malaysia.

\section{Conclusion}

In conclusion, this study has explained all the necessary analysis for this research. This research has analyzed the data collected from 120 respondents. Also, pilot study, descriptive analysis, reliability test, normality test, linearity test, correlation analysis and multiple regression analysis are tested by using the SPSS software. Overall finding shows that there is only one variable supported the dependent variable which is nature of business operation and others variable are not supported by the dependent variable which are age of borrowers, diversion of funds by borrowers and repayment schedule.

\section{References}

Aaker, D. A., Kumar, V., \& Day, G. S. (2007). Marketing research (9th ed.). Massachusetts: Wiley.

Ahmad, S. A. (1997). Natural Hazards and Hazard Management in the Greater Caribbean and Latin America Publication No. 3.

Alex, A. K. (2014). Causes and Control of Loan Default/Delinquency in Microfinance Institutions in Ghana. American International Journal of Contemporary Research, 4(12), 36-45

Arene, C. J. (1993). An analysis of loan repayment potentials of smallholder soyabean group farmers in Nigeria. Quarterly Journal of International Agriculture, 32(1), 160-169.

Balogun, E. D., \& Alimi, A. (1990). Loan Delinquency among Small Farmers in Developing Countries: A Case Study of the Small-Farmer Credit Programme in Lagos State of Nigeria. CBN Economic and Financial Review, 26(3).

Berita, H. (2009a). PUNB sasar salurkan pinjaman RM164.3 juta.

Berita, H. (2009b). TEKUN non-performing loans RM225 million. Berita Harian.

Besley, T., \& Coates, S. (1995). Group lending, repayment incentives and social collateral. Journal of Development Economics, 46, 1-18. https://doi.org/10.1016/0304-3878(94)00045-E

Bloem, M. A., \& Gorter N.C. (2001). Treatment of Nonperforming Loans in Macroeconomic statistics, IMF Working Paper, WP/01/209.

Charles, M., Raphael, G., Dorcas, O., \& Kwadwo, B. Y. (2013). The Relationship between Loan Default and Repayment Schedule in Microfinance Institutions in Ghana: A Case Study of Sinapi Aba Trust. Research Journal of Finance and Accounting, 4(19), 165-175.

Chaudhary, M. A., \& Ishfaq, M. (2003). Credit worthiness of rural borrowers of Pakistan. The Journal of Socio-Economics, 32, 675-684. https://doi.org/10.1016/j.socec.2003.10.005

Dadson, A. V. (2012). Determinants of loan repayment default among farmers in Ghana. Journal of Development and Agricultural Economics, 4(13), 339-345.

Ernst, \& Young, L. L. P. (2004). Global Nonperforming Loan Report 2004.

Ethel, N. N. T. (2011). Assessment of Loan Quality: Evidence From Listed Banks (Doctoral Dissertation, University of Science and Technology). Retrieved from http://ir.knust.edu.gh/bitstream/123456789/4323/1/Ethel\%20Naa\%20Nueki\%20Tetteh.pdf

Eze, C. C. \& Ibekwe, U. C. (2007). Determinants of loan repayment under the indigenous financial systems in Southeast, Nigeria. Journal of social science, 2(2), 116-120.

Field, E. \& Pande, R. (2008). Repayment frequency and default in microfinance: evidence from India. Journal of the European Economic Association, 6(2-3), 501-509. https://doi.org/10.1162/JEEA.2008.6.2-3.501

Fikirte, K. (2011). Determinants of loan repayment performance: A case study in the Addis Credit and Saving Institution. Wegeningen University: Netherlands.

Florence, A. \& Daniel, N. W. (2014). Factors Influencing Loan Repayment in Micro-Finance Institutions in Kenya. IOSR Journal of Business and Management, 16(9), 66-72. https://doi.org/10.9790/487X-16936672 
Godquin, M. (2004). Microfinance repayment performance in Bangladesh: how to improve the allocation of loans by MFIs. World Development, 32(11), 1909-1926. https://doi.org/10.1016/j.worlddev.2004.05.011

Guildford. (2006). Guildford's suggested Interpretation for Correlation Coefficient Value. Retrieved from http://www.acf.dns.gov/programs/cb/pubs/cw002/appendix/appendix G.html

Guttman, J. E. (2007). Repayment performance in microcredit programs: theory and evidence. Working Paper. Networks Financial Institute. Indiana State University. March 2007.

Hair, J. F., Jr, Anderson, R. E., Tatham, R. L., \& Black, W. C. (1998). Multivariate data analysis (5th ed.). Upper Saddle River,NJ: Prentice-Hall.

Hair, J. K., Black, B. R., Babin, H. B., Anderson, P. R., \& Tatham, C. R. (2006). Multivariate data analysis (6th ed.). New Jersey. Pearson Education, Inc.

Kibrom, T. G. (2010). Determinants of Successful Loan Repayment Performance of Private Borrowers in Development Bank of Ethiopia, North Region. (Master's thesis, Mekelle University).

Mokhtar, S. H., Gilbert, N., \& Christopher, G. (2012). Determinants of microcredit loans repayment problem among microfinance borrowers in Malaysia. International Journal of Business and Social Research (IJBSR), 2(7), 33-45.

Munene, H. N. \& Guyo, S. H. (2013). Factors Influencing Loan Repayment Default in Micro-Finance Institutions: The Experience of Imenti North District, Kenya. International Journal of Applied Science and Technology, 3(3), 80-84

Mungai, J. N. (2015). Loan Repayment And Sustainability Of Government Revolving Funds In Murang'a County, Kenya. (Doctoral Dissertation, Kenyatta University). Retrieved from http://ir-library.ku.ac.ke/bitstream/handle/123456789/13363/loan\%20repayment\%20and\%20sustainability $\% 20$ of\%20government $\% 20$ revolving\%20funds.....pdf? sequence=1\&isallowed $=\mathrm{y}$

Murray, J. (2011). Default on a loan. United States Business Law and Taxes Guide. Retrieved from http://biztaxlaw.about.com/od/glossaryd/g/default.htm

Nawai, N. B., \& Mohd Shariff, M. N. (2013). Determinants Of Repayment Performance In Microfinance Programs In Malaysia. Labuan Bulletin of International Business \& Finance, 11, 14-29

Njoku, J. E. (1997). Determinants of loan repayment under the special emergency loan scheme (SEALS) in Niger: A case study in Imo state. African Review of Money Finance and Banking, 1, 39-51.

Norell, D. (2001). How to reduce arrears in microfinance institutions. Journal of Microfinance, 3(1), 115-130.

Norhaziah, B. N., \& Mohd Noor, B. M. S. (2013). Determinants of Repayment Performance in Microfinance Programs in Malaysia. Labuan Bulletin of International Business \& Finance, 11, 15.

Norma, M. S., \& Jarita, D. (2011). An Economic Impact Assessment of a Microcredit Program In Malaysia: The Case Of Amanah Ikhtiar Malaysia (Aim). International Journal of Business and Society, 12(1), 1-14

Nunnally, J. C. (1981). Psychometric theory. (2nd Ed). New Delhi: Tata McGraw-Hill publishing Co Ltd.

Ochung, K. O. (2013). Factors Affecting Loan Repayment among Customers of Commercial Banks in Kenya: A Case Of Barclays Bank Of Kenya, Nairobi County. (Master's thesis, University of Nairobi).

Oklen, F., \& Rotem, D. (1986). Simple Random Sampling from Relational Database. Paper presented at the Twelfth International Conference on Very Large Data Bases. Retrieved from http://www.vldb.org/conf/1986/P160.PDF

Okorie, A. (1986). Major determinants of agricultural smallholder loan repayment in a developing economy: Empircal evidence from Ondo State, Nigeria. Agricultural Administration, 21, 223-234. https://doi.org/10.1016/0309-586X(86)90040-3

Pearson, R., \& Greef, M. (2006). Causes of Default among Housing Micro Loan Clients. FinMark Trust, Midrand.

Rashid, M. K. (2014). Causes of Default on Micro - Credit among Women Micro-Entrepreneurs in Kenya. A Case Study of Women Enterprise Development Fund (Wedf) Msambweni Constituency. Journal of Economics and Finance, 3(6), 32-47

Roslan, A. H., \& Abd Karim, M. Z. (2009). Determinants of microcredit repayment in Malaysia: The case of Agrobank. Humanity \& Social Sciences Journal, 4(1), 45-52. 
Sayed, S., Izaidin, M., Syaiful, R., Muhamad, M. R., Sarah, H., \& Nlizwa, R. (2015). The Impact of Microfinance on Poverty Reduction: Empirical Evidence from Malaysian Perspective. Procedia - Social and Behavioral Sciences, 195, 721-728. https://doi.org/10.1016/j.sbspro.2015.06.343

Sekaran, U. (2003). Research Method for Business: A Skill Building Approach (4th ed.) New York: John Wiley $\&$ Sons.

Shaik, A. M. (2014). Performance of Loan Repayment Determinants in Ethiopian Micro Finance - An Analysis. Eurasian Journal of Business and Economics, 7(13), 29-49

Sharma, M., \& Zeller, M. (1997). Repayment performance in group based credit programmes in Bangladesh. World Development, 25(10), 1731-1742. https://doi.org/10.1016/S0305-750X(97)00063-6

TEKUN Nasional. (2012). Retrieved from http://www.tekun.gov.my/

TEKUN. (2009). Yearly performance report. Kuala Lumpur: TEKUN.

TEKUN. (2013). Tabung Ekonomi Kumpulan Usaha Niaga.

Veronica. (2013). The Influence of Students' Loans Borrowers' Characteristics on Default Rate in Tanzania. Canadian Center of Science and Education, 3(4), 26-49.

Walter, O. B. \& Lilian, A. (2013). Causes of Loan Default within Micro Finance Institutions in Kenya. Interdisciplinary Journal of Contemporary Research In Business, 4(12), 316-335.

Wongnaa, C. A. \& Awunyo, D. V. (2013). Factors Affecting Loan Repayment Performance Among Yam Farmers in the Sene District, Ghana. Economics and Informatics, 5(2), 111-122.

YUM. (2009). Yayasan Usaha Maju Notes. Kota Kinabalu: Yayasan Usaha Maju.

YUM. (2014). Yayasan Usaha Maju Sabah.

\section{Copyrights}

Copyright for this article is retained by the author(s), with first publication rights granted to the journal.

This is an open-access article distributed under the terms and conditions of the Creative Commons Attribution license (http://creativecommons.org/licenses/by/4.0/). 